\title{
Differential OER Impacts of Formal and Informal ICTs: Employability of Female Migrant Workers
}

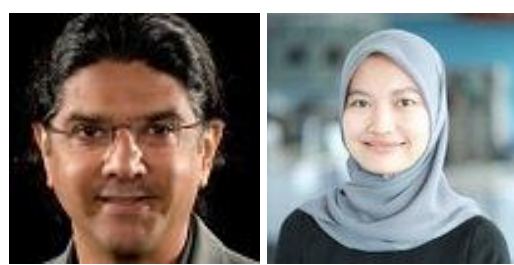

Arul Chib and Reidinar Juliane Wardoyo Nanyang Technological University

\begin{abstract}
Information and communication technologies aid marginalized groups in seeking social support, building proximate networks, and improving employment opportunities. However, one key factor that is understudied in the literature is the impact of open education resources (OER) on the employability of marginalized groups. This study focuses on open and distance learning in the context of low-income female migrant domestic workers as a marginalized community. Specifically, we assessed the differential effects of two types of communication: informal OER resources (e.g., social media, mobile calling, texting) and formal OER resources (e.g., classroom prescribed learning tools and lectures) on specific development outcomes of functional literacy and perceived employability. A survey was conducted amongst female migrant domestic workers $(\mathrm{n}=100)$ enrolled in the Indonesian Open University in Singapore. Results indicate that access to OER resources via computers in the formal context of institutional learning, when combined with employability awareness, had a significant influence on livelihood outcomes, i.e., perceived employability. However, this did not lead to actual improvements in learning - functional literacy. Instead, actual learning improvement was influenced by digitals skills enabled by mobile phones and computers. The study concludes with a discussion on the policy implications for digital skills training via mobile devices for marginalized populations to bolster the positive effects of OER on livelihood outcomes.
\end{abstract}

Keywords: open and distance learning, open education resources, employability, literacy, migration 


\section{Introduction}

Open educational resources (OER) have been defined by the Organization for Economic Co-operation and Development (OECD; Orr, Rimini, \& Van Damme, 2015) as "digital learning resources offered online ...freely and openly to teachers, educators, students, and independent learners in order to be used, shared, combined, adapted, and expanded in teaching, learning and research" (p.17). We argue (Bentley \& Chib, 2016) that such a definition, focusing on the uses of the technology, ignores the societal impact of digital openness. Reilly and Smith (2013), in their book on open development, propose that information and communication technologies (ICTs) have the potential to facilitate improvements in the lives of people. In the context of marginalized groups, while ICTs have been shown to aid transnational blue-collar migrants in improving their employment opportunities via adaptation (Elias \& Lemish, 2008) and formation of social networks (Law\& Peng, 2006), one key factor that is under-studied in the literature is the impact of OER on employability.

OER are increasingly playing a role in distance learning systems in many parts of the world. Distance learning offers flexible learning opportunities, allowing minimization of constraints in terms of access, time and place, pace, and method of study (UNESCO, 2008). This means that distance learning, facilitated by the open educational resources available, offers enhanced access for groups customarily constrained from attending traditional institutions, such as secondary school graduates who fail to gain admission to university, women with domestic responsibilities, learners residing in remote rural areas, and impoverished or socially marginalized communities (Saint, 2003). The present study focuses on lowincome female migrant domestic workers as a marginalized community, and examines their increased employment opportunities after attending open and distance learning (ODL) programmes enhanced by OER.

As a consequence of globalization, demographic shifts, conflicts, and income inequalities, transnational migrant workers have been increasingly departing their countries of origin in search of employment and security (International Labour Organization [ILO], n.d.). According to the United Nations Educational, Scientific, and Cultural Organization, women made up $48 \%$ of all international migrants worldwide (UNESCO, 2013), with over 17 million undertaking domestic work in Asia (International Labour Organization [ILO], 2013). In Singapore, where this study is situated, the number of migrant domestic workers totaled 239,700 (Ministry of Manpower, 2016), around half of whom were Indonesian (Thomas \& Lim, 2011). Blue-collar migrant workers manifest stress from isolation and homesickness (Chib, Wilkin, \& Mei Hua, 2013), often compounded by social discrimination (Aricat, Karnowski, \& Chib, 2015; Qiu, 2009), stringent labor laws regarding employment mobility and labor rights (Humanitarian Organization for Migration Economics [HOME], 2015), and financial barriers to engaging in enrichment classes (Nguyen Chib, \& Mahalingam, 2017). The relative isolation is often worse for female domestic workers employed in individual households, who have little private physical space (Hsia \& Smales, 2010) or social freedoms (Thompson, 2009).

A stream of past research has specifically recognized female migrant workers' information and communication technologies skills to seek social support for alleviating stress in the destination country (Chib et al., 2013), building proximate networks to socially integrate into the destination country (Diminescu, 2008), and performing duties as transnational mothers (Chib, Malik, Aricat, \& Kadir, 2014; Madianou \& Miller, 2011). Past research has also elaborated migrant workers' ICT skills in the open education context, for instance in terms of self-initiated learning, in which foreign workers use mobile phone features to learn languages and access news (Chib \& Aricat, 2016). 
While studies on digital skills for social support and self-initiated learning have been well documented, few studies have explored migrant workers' use of OER for learning. Conversely, the OER literature has traditionally overlooked the advent of the most highly diffused communication tool of mobile telephony, with exceptions in the nascent field of mLearning (Park, 2011; Traxler, 2010). We aim to bridge the gap conceptually by examining the differential impact of digitals skill (i.e., computer and mobile phone) at both personal (i.e., daily communication, entertainment) and institutional (i.e., distance learning at the Open University) levels. Specifically, we assessed the differential effects of two types of communication: informal OER resources (e.g., social media, mobile calling, texting) and formal OER resources (e.g., classroom prescribed learning tools and lectures) on specific development outcomes of functional literacy and perceived employability.

\section{Formal Open Educational Resources in Distance Education}

The field of ODL has changed considerably since the 1960s when distance learning emerged, primarily due to the success of Britain's Open University model, and its many global counterparts (Perraton, 2012). Now, ODL goes hand-in-hand with flexible networked technologies, typically including technology-based interaction as a key element. We therefore adopt Keegan's (1996) view of open distance education, which combines the quasi-permanent separation of teacher and learner throughout the length of the learning process with provision of teaching materials and student support services that are enhanced by technology, such as print, audio, video, or digital resources. Two-way communication and occasional meetings are utilized for both didactic and socialisation purposes.

In a review of OER in developing countries, Bentley and Chib (2016) found that a majority of the studies claiming improved learning outcomes focused on the perspective of teachers, with little emphasis on pedagogical practices. Some scholars (de Hart, Chetty, \& Archer, 2015) find significant institutional barriers to participation in OER initiatives in South Africa, while others find barriers to instructors' intention to adopt and use OER in Tanzania (Mtebe \& Raisamo, 2014). A key missing ingredient, in studies that focus on the institutional perspective delivering digital content via computers in classrooms, is the ubiquitous availability of informal OER resources via mobile devices in students' lives.

There is a nascent literature (outside of mLearning) that focuses on mobile devices as sites for OER. For example, in terms of technological elements within open education, mobiles have emerged as significant learning tools for remote and marginalized students. Young and Hung (2014) find diverse use of OpenCourseWare within the Chinese diaspora from a variety of tablets and smartphones, yet do not provide evidence of learning outcomes. Traxler (2010) and Wagner (2005), on the other hand, have argued that mobile learning should not focus on techno-centric framings of learning and pedagogical practice. However, Ali and Samaka (2013) argue that there is reason to explore the significance of mobile technology to close the digital and educational access divide for marginalized students in open education. Students may be engaging in study for shorter periods of time on their mobiles, and will thus be better suited to learn in short bursts, or by dictating or recording videos instead of typing. However, many of these benefits have not been tested in formal education, and as Beckman (2010) remarks, lecturers may not receive adequate support to reconsider pedagogical designs. This institutional support may only come to fruition if it is shown that informal mobile learning is not only advantageous but necessary for successful student engagement in OER programmes.

\section{Informal Digital Resources for Marginalized Populations}


For Indonesian migrant domestic workers in Singapore, the assumption is that ODL offers increased access and flexibility to gain access to higher education, while solving constraints related to limited time, income, and mobility. However, in reality, few of these programmes have provided specific evidence of impact, beyond learning skills, especially for marginalized students who may have distinct technological skills and habits due to their backgrounds and difficult working conditions. Prior investigations into OER in Indonesia offer technological proposals (Selviandro, Suryani, \& Hasibuan, 2014) or evaluation of student perceptions (Harsasi, 2015), yet fail to suggest any improvement in their lives and livelihoods.

This paper explores the contributions of two perspectives on technological contributions to ODL: computer and mobile technological mediums, and formal and informal contexts of interaction in open distance learning programmes. Research has established a variety of complementary benefits of mobile use for migrant workers. These studies suggest that personal mobile phone use is likely critical for student engagement in open education programmes; yet this claim cannot yet be made strongly. Past studies have shown that mobile phone skills enabled informal and organic (i.e., self-initiated) learning on the part of migrant workers. Mobile phones enabled migrant workers and their families to learn about transnational livelihoods when they shared stories on what it was like to be a migrant worker in the destination countries (Cuban, 2014). For the latter objective, migrant workers used online dictionaries and English news over FM radio in mobile phones to help them learn English and improve knowledge on issues (Chib \& Aricat, 2012). Mobile phones also facilitated semi-skilled workers to clarify technical doubts with their supervisors when on duty, thus making them self-learners and self-explorers at the same time (Chib \& Aricat, 2012).

While past research has provided useful insights on ICT skills for personal use, this study fills a research gap by investigating migrant domestic workers' OER usage for livelihood outcomes. Studies have shown that ICT-based learning can reduce some aspects of social exclusion in terms of encouraging minority ethnic group learners to speak more within the host community (Webb, 2006). Noting the potential for migrant workers to use technology for learning (e.g., Kluzer, Ferrari, \& Centeno, 2009), we investigate how migrant domestic workers use mobile technology to supplement formal learning at an open educational institution. We further investigate the differential impact of this learning process on specific outcomes such as functional literacy and employability.

\section{Measuring Personal and Institutional Contributions to Development Outcomes Functional Literacy}

The first learning outcome that we investigate is functional literacy, which has numerous conceptualizations. This study adopts UNESCO's (1978) definition that describes it as literacy that is required for an effective functioning of one's group and community, and also for enabling a person to read, write, and calculate for one's self and the community's development. Functional literacy is thus emphasized to focus on the skills that can assist individuals to perform tasks essential for work and everyday living (Atkinson, 2014; Hayes \& Valentine, 1989). Functional literacy can also strengthen individuals' capabilities to access health, educational, and economic services, which may contribute to their pursuit of development (UNESCO, 2008).

Functional literacy is an important construct, particularly in relation to migrant domestic workers, who constitute a low social class in Singapore due to their blue-collar occupations, limited wages, and migration status. Research suggests that functional literacy can help facilitate the social integration of marginal groups in society (Kagitcibasi, Goksen, \& Gulgoz, 2005; Levine, 1994). Functional literacy is also seen from an empowerment perspective, particularly for women, in terms of self-esteem, economic 
independence, and self-confidence (UNESCO, 2008). When women are able to exercise their literacy, the impact was even greater, as they were more likely to be able to support their children in practical ways, such as sending their children to school, thus contributing to literate societies in general (Carr-Hill, 2001).

ICTs can play an important role in the achievement of functional literacy. Several studies have examined the influence of digital resources on adult literacy skills. Eady, Herrington, and Jones (2010), for instance, developed computer applications that incorporated literacy skill-building opportunities, finding that the learners were proficient in the use of the application. Electronic dictionaries have supported learners to better understand content- specific vocabulary, which then improved literacy skills (Silver-Pacuilla, 2006). With this background, we propose that ICTs skills (mobile phone and computer) and OER access, both informally via mobile phones, and through formal institutional resources (for example, distance learning course at an Open University level) will lead to improved functional literacy amongst migrant domestic workers. Specifically, we put forward that:

H1a: The skill to use mobile phones by migrant domestic workers will positively influence their functional literacy.

H1b: Informal access to OER resources via mobile phone by migrant domestic workers will positively influence their functional literacy.

H2a: The skill to use computers by migrant domestic workers will positively influence their functional literacy.

H2b: Formal access to OER resources via computer at the institutional level by migrant domestic workers will positively influence their functional literacy.

\section{Perceived Employability}

Employability in general refers to a process and factor that allows people to seek, maintain, and adapt to numerous employment opportunities (Fugate, Kinicki, \& Ashforth, 2004; Garrido, Sullivan, \& Gordon, 2012). The term employability has been used in various fields, including employment and public policy (Hillage \& Pollard, 1998), education (Smith, McKnight, \& Naylor, 2000), and economics (Brown, Hesketh, \& Williams, 2003). The popularity of this concept has developed in part due to the shift in global business and policy from long-term tenure to short-term arrangements in formal employment (Berntson, Sverke, \& Marklund, 2003). This implies that in a job market environment where there is a decrease in job security and a lack of long-term employment, individual assets are becoming very important (Rothwell \& Arnold, 2007). Personal attributes such as skills, competence, and experience, may increase individuals' competitiveness. Even in situations when they remain in the same position in the labor market, their employability is likely to be enhanced.

This study examines employability as a person-centered construct, which means "adaptability that enables workers to identify and realize career opportunities" (Fugate, Kinicki, \& Ashforth, 2004, p. 21) and "what people believe their employment options are" (Rothwell \& Arnold, 2007, p. 24). This construct is important for the respondent group because positive effects on employment further contribute to economic wellbeing and quality of life. Additionally, gainful employment provides income and other benefits such as social security, health insurance, and legal protections (Gerards, De Grip, \& Witlox, 2014). 
Past studies have examined the relationship between ICTs and employability (Atasoy, 2013; Suhaida, Nurulhuda, \& Yap, 2013). The diffusion of ICTs across all economic sectors has increased the demands in terms of workers' digital skills to adapt to the changing job market (Garrido, Sullivan, \& Gordon, 2012), with digital skills increasingly crucial for people entering the labor market and those trying to seek a better job (Lindsay, 2005). Governments worldwide consider ICTs as means to enhance competitiveness by raising productivity and transforming business processes as well as contributing to employment, which eventually spur economic and social growth (World Bank, 2013).

Digital skills have increasingly been viewed as an important component of employability (Belt \& Richardson, 2005). Computer skills, for instance, catalyze self-directed learning and widen access to social networks that eventually promote employability, especially for those in the job-search process (Lindsay, 2005). For disadvantaged and vulnerable groups who experience high levels of social anxiety and loneliness, telephone and internet access served as a means where they could find a safe and anonymous environment to build social relationships (Haddon, 2000; McKenna \& Bargh, 2000). From a gender perspective, quite relevant to this study, the internet provides wide access to job market information, which increases the employability of women with ICT skills to participate in the labor market (Suhaida et al., 2013).

Despite the importance of digital skills to enhance employability, it is important to note that if most workers possess them, the value of the skills may diminish and hiring decisions may be based on other criteria (Garrido, Sullivan, \& Gordon, 2012). For the purposes of this paper, factors such as education must be considered to develop one's skills (Brown, Murphy, \& Nanny, 2003). As noted in the previous section on OER, an identified research gap was to examine the effects of open educational resources on livelihood outcomes. We propose that the ability to access open educational resources via mobile phones and computers will positively influence one's employability.

H3a: The skill to use mobile phones by migrant domestic workers will positively influence their employability.

H3b: Informal access to OER resources via mobile phone by migrant domestic workers will positively influence their employability.

H4a: The skill to use computers by migrant domestic workers will positively influence their employability.

H4b: Formal access to OER resources via computer at the institutional level by migrant domestic workers will positively influence their employability.

Past studies suggest that functional literacy, such as writing, reading, and math skills, are essential to function at work and everyday living, and hence has potentials to enhance individuals' employability (Atkinson, 2014; Hayes \& Valentine, 1989). We hypothesize that:

H5: Functional literacy will positively influence employability.

An additional item on employability awareness (Gerards et al., 2014) was included to account for whether employment was a desirable outcome for the domestic workers. The full model is visualized in Figure 1. 
Mobile Phone (Informal)

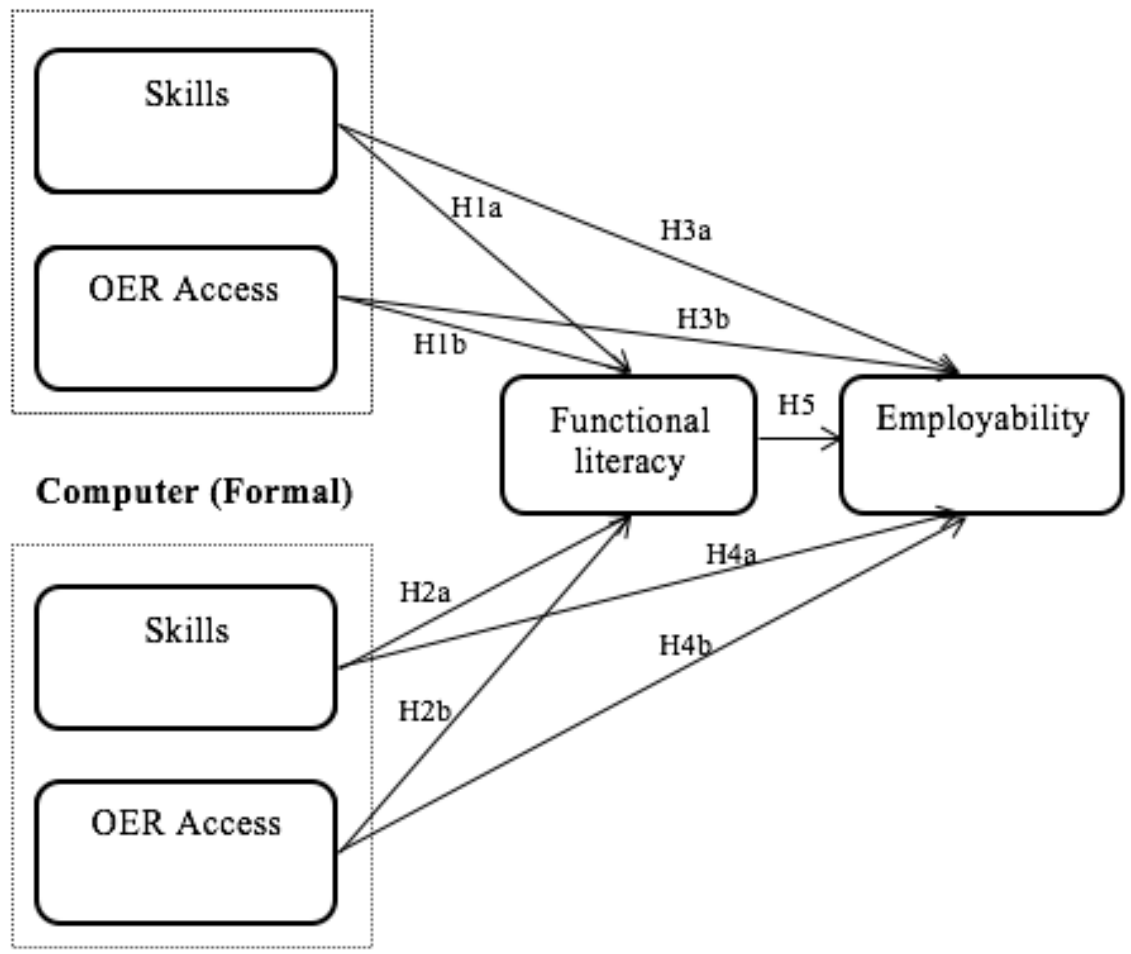

Figure 1. Conceptual framework.

\section{Method}

\section{Participants and Procedures}

We conducted a survey with 100 Indonesian domestic workers enrolled at the Open University (OU) in Singapore ranging in ages between 24-38. The participants were enrolled in different areas of studies at the OU, with accountancy and management the most popular choices in our sample. We examined female migrant domestic workers due to the following reasons. First, their employment and living circumstances are socially isolated; hence their access and use of ICTs provides for an interesting and significant research context. Second, these domestic workers were all women, thus the results may be used to inform policy decisions with regard to the impact of women's education and ICTs skill on employability and literacy.

We obtained ethical approval from Nanyang Technological University's Institutional Review Board. The respondents were selected based on their availability, meaning that those who were available during data collection period at the Open University were recruited to participate. The survey was administered in halls or classrooms. Prior to survey administration, we provided detailed instructions and consent forms to the participants. Participation was completely voluntary and participants were encouraged to ask questions as necessary. Each survey session lasted around 30 to 45 minutes. The participants were given incentives in the form of vouchers. In total, 110 survey questionnaires were distributed, and 100 valid questionnaires were collected, yielding a response rate of $91 \%$.

\section{Measures}


We translated the questionnaire from English to Bahasa Indonesia to respond to the needs of our Indonesian participants. We then translated the questionnaire back to English to ensure accuracy of the translation. The questionnaire included measures for mobile phone skill, access to OER via mobile phones, computer skill at personal level, access to OER via computers at institutional level, functional literacy, employability awareness and perceived employability. Confirmatory Factor Analyses (CFA) revealed that all the scales consisted of items that had factor loadings of 6 and above. Reliability analyses were conducted to achieve acceptable Alphas. Table 1 displays the descriptive statistics and reliability scores for variables on the 5-point Likert scales used, anchored from strongly disagree (1) to strongly agree (5), except as noted. The questionnaire also collected demographic information such as monthly income and programme selection of participants.

Table 1

Descriptive Statistics for Key and Background Variables

\begin{tabular}{llll}
\hline & M & SD & a \\
\hline Mobile phone skill & 3.70 & .81 & .96 \\
\hline Access to OER via Mobile phones & 3.33 & 1.15 & .91 \\
\hline Computer skill & 3.81 & .64 & .91 \\
\hline Access to OER via Computers & 3.01 & 1.27 & .93 \\
\hline Functional literacy & 4.09 & .55 & .95 \\
\hline Employability awareness & 4.23 & .52 & .61 \\
\hline Perceived employability & 4.12 & .57 & .86
\end{tabular}

Note $. \mathrm{M}=$ Construct mean, $\mathrm{SD}=$ Standard deviation, $\alpha=$ Cronbach's alpha.

Mobile phone skills were measured by asking participants to rate how well they use mobile phone for nine activities (e.g., texting, make/receive call, change wallpaper properties, change the phone settings, perform an internet search, access, and chat using instant messaging) on 5-point scales, anchored on no knowledge (1), beginner (2), good (3), intermediate (4), and expert (5). The items were modified from Madigan, Goodfellow, and Stone (2007).

OER access via mobile phones at the personal level was measured by asking participants to rate how often they used the mobile phone for eight activities of informal learning (e.g., make or receive call to discuss assignments or study materials with OU friends, access and/or download online materials from OU websites, access/search materials online, access OU Facebook Group to discuss assignments and study materials with OU friends) on 5-point scales, anchored on never (1), once a month (2), once a week (3), once a day, (4), and several times a day (5).

Computer skills were measured by asking participants to rate how confident they were in performing 10 activities (e.g., I feel confident using a computer/laptop, I feel confident making selections from an onscreen menu, I feel confident escaping or exiting from a program or software, I feel confident understanding terms/words relating to computer hardware (e.g., keyboard, monitor, disk drives). The items were adapted from Barbeite and Weiss (2004).

OER access via computers at the institutional level was measured by asking participants to rate how often they used computers for seven activities of formal learning (e.g., access and/or download online materials from OU websites, access/search materials online, access OU Facebook Group to discuss assignments 
and study materials with OU friends) on 5-point scales, anchored on never (1), once a month (2), once a week (3), once a day (4), and several times a day (5).

Functional literacy was measured by asking participants 17 items pertaining to everyday reading and writing tasks (e.g., I know how to fill out an income tax form), math and measurement tasks (e.g., I know how to budget my money), and special literacy tasks (e.g., I know how to read and use road maps and city maps). The items were adapted from Hayes and Valentine (1989).

Employability awareness was measured by asking participants four items including "I myself am responsible for my future development," and "I have a clear view of how I want to develop myself in the years to come." The items were adapted from Gerards et al. (2014).

Self-perceived employability was measured by asking participants 10 items (e.g., the skills I have gained in OU are transferable to other occupations, I could easily retrain to make myself more employable elsewhere, I can use my professional networks and business contacts to develop my career, I have a good knowledge of opportunities for me outside of my current job even if they are quite different to what I do now). The items were adapted from Rothwell and Arnold (2007).

Analyses were run using hierarchical multiple regression in SPSS software. The participants' age and income were entered in the first block as controls to ensure that these variables did not explain away the entire association between the independent and the outcome variables.

\section{Results}

We first examined the zero-order correlations among variables to detect if there was any multicollinearity in the dataset (Table 2). No high correlations were noted, suggesting that there were no multicollinearity issues.

Table 2

Zero-Order Correlations Among the Variables

\begin{tabular}{lrrrrrr}
\hline Variable & 1 & \multicolumn{1}{c}{2} & 3 & 4 & 5 & 6 \\
\hline 1. OER Access via mobile phones & 1 & & & & & \\
2. OER Access via computers & $.819^{* *}$ & 1 & & & & \\
3. Mobile phone skills & $.297^{* *}$ & $.248^{*}$ & 1 & & & \\
4. Computer skills & $.314^{* *}$ & $.363^{* *}$ & $.403^{* *}$ & 1 & & \\
5. Employability awareness & .092 & -.021 & $.225^{*}$ & $.377^{* *}$ & 1 & \\
6. Functional literacy & .174 & .158 & $.449^{* *}$ & $.611^{* *}$ & $.510^{* *}$ & 1 \\
7. Perceived employability & $.281^{* *}$ & $.266^{*}$ & $.312^{* *}$ & $.486^{* *}$ & $.350^{* *}$ & $.442^{* *}$ \\
\hline
\end{tabular}

${ }^{*} p<.05,{ }^{* *} p<.01$

H1 predicted that (a) the skill to use a mobile phone, and (b) access to OER via mobile phones at the personal level, would positively influence functional literacy, whereas H2 predicted that (a) the skill to use a computer, and (b) access to OER via computers at the institutional level, would positively influence functional literacy. As Table 3 shows, the block of demographics were not significantly related to functional literacy. The variables in step 2 added $38.6 \%$ of variance to the equation $(\mathrm{R} 2=.434$, 
$\mathrm{F}(6,56)=7.157, \mathrm{p}<.001)$ with age $(\beta=.257, \mathrm{p}<.05)$, mobile phone skills $(\beta=.357, \mathrm{p}<.01)$, and computer skills ( $\beta=.492, \mathrm{p}<.001$ ), positively influencing functional literacy. In the final model, employability awareness added a significant $9.8 \%$ of variance $(\beta=.343, \mathrm{p}<.001)$. Hence, H1a and H2a were supported whereas $\mathrm{H} 1 \mathrm{~b}$ and $\mathrm{H} 2 \mathrm{~b}$ were rejected.

Table 3

\section{Predictors of Functional Literacy}

\begin{tabular}{lccr}
\hline \multicolumn{1}{c}{ Regression steps } & $B$ & $S E$ & \\
\hline Step 1 & & & \\
Age & .006 & .014 & .057 \\
Income & .212 & .148 & .193 \\
$R^{2}$ & & .048 & \\
$F$ & & 1.511 & \\
$d f$ & & 2.60 & \\
Step 2 & & & $.257^{*}$ \\
Age & .026 & .012 & -.148 \\
Income & -.163 & .135 & -.174 \\
Access to OER via mobile phones & -.091 & .080 & -.012 \\
Access to OER via computers & -.006 & .074 & $.357^{* * *}$ \\
Mobile phone skills & .252 & .088 & $.492^{* * *}$ \\
Computer skills & .449 & .112 & \\
$\square R^{2}$ & & $.386^{* * * *}$ & \\
$F$ & & 7.157 & $.257^{*}$ \\
$d f$ & & 6.56 & -.155 \\
Step 3 & & & -.225 \\
Age & .026 & .011 & .099 \\
Income & -.171 & .124 & $.329^{* * *}$ \\
Access to OER via mobile phones & -.118 & .074 & $.349^{* * *}$ \\
Access to OER via computers & .047 & .070 \\
Mobile phone skills & .231 & .081 & \\
Computer skills & .337 & .108 & \\
Employability Awareness & .416 & .123 & \\
$\square R^{2}$ & & $.098^{* * * *}$ & \\
$F$ & & 8.931 & \\
$d f$ & & 7.55 & \\
Total $R^{2}$ & & .532 & \\
\hline
\end{tabular}

Note. ${ }^{*} p<.05,{ }^{* *} p<.01,{ }^{* * *} p<.001$.

$\mathrm{H} 3$ predicted that (a) the skill to use a mobile phone, and (b) access to OER via mobile phones at the personal level, would positively influence perceived employability, whereas $\mathrm{H}_{4}$ predicted that (a) the skill to use a computer, and (b) access to OER via computers at the institutional level, would positively influence perceived employability. As Table 4 shows, the model in step 2 and 3 failed to reach statistical significance after controlling for differences in age and income. Hence, mobile phone and computer skills, access to OER via mobile phones or via computers at the institutional level, and functional literacy, were not significantly associated with perceived employability. However, in the final step, employability awareness added a significant $6.4 \%$ of variance in predicting perceived employability. A significant regression equation was found for step $4(\mathrm{R} 2=.265, \mathrm{~F}(8,51)=2.300, \mathrm{p}<.05)$ with access to OER resources via computers at the institutional level and employability awareness being positive predictors of perceived employability ( $\beta=.453, \mathrm{p}<.05$ and $\beta=.311, \mathrm{p}<.05$ respectively). Hence, H3a, H3b, and $\mathrm{H}_{4} \mathrm{a}$ were rejected whereas $\mathrm{H} 4 \mathrm{~b}$ was supported. 
Table 4

Predictors of Perceived Employability

\begin{tabular}{|c|c|c|c|}
\hline Regression steps & $B$ & $S E B$ & $\beta$ \\
\hline \multicolumn{4}{|l|}{ Step 1} \\
\hline Age & -.015 & .012 & -.177 \\
\hline Income & .057 & 130 & .061 \\
\hline$R^{2}$ & & .028 & \\
\hline$F$ & & .811 & \\
\hline$d f$ & & 2,57 & \\
\hline \multicolumn{4}{|l|}{ Step 2} \\
\hline Age & -.003 & .012 & -.041 \\
\hline Income & -.054 & 144 & -.058 \\
\hline Access to OER via mobile phones & -.098 & .083 & -.223 \\
\hline Access to OER via computers & .144 & .079 & .349 \\
\hline Mobile phone skills & -.019 & .099 & -.031 \\
\hline Computer skills & .248 & .151 & .314 \\
\hline$\square R^{2}$ & & .178 & \\
\hline$F$ & & 1.918 & \\
\hline$d f$ & & 6,53 & \\
\hline \multicolumn{4}{|l|}{ Step 3} \\
\hline Age & -.009 & .013 & -.101 \\
\hline Income & -.011 & .147 & -.011 \\
\hline Access to OER via mobile phones & -.082 & .084 & -.187 \\
\hline Access to OER via computers & .145 & .079 & .352 \\
\hline Mobile phone skills & -.079 & .110 & -.132 \\
\hline Computer skills & .182 & .135 & .230 \\
\hline Functional literacy & .179 & 146 & .208 \\
\hline$\square R^{2}$ & & .023 & \\
\hline$F$ & & 1.874 & \\
\hline$d f$ & & 7,52 & \\
\hline \multicolumn{4}{|l|}{ Step 4} \\
\hline Age & -.004 & .013 & -.047 \\
\hline Income & -.054 & .144 & -.058 \\
\hline Access to OER via mobile phones & -.118 & .083 & -.268 \\
\hline Access to OER via computers & .186 & .079 & $.453^{*}$ \\
\hline Mobile phone skills & -.044 & .108 & -.074 \\
\hline Computer skills & .154 & .131 & .194 \\
\hline Functional literacy & .026 & .159 & .031 \\
\hline Employability awareness & .320 & .152 & $.311^{*}$ \\
\hline$\square R^{2}$ & & $.064^{*}$ & \\
\hline$F$ & & 2.300 & \\
\hline$d f$ & & 8,51 & \\
\hline Total $R^{2}$ & & .265 & \\
\hline
\end{tabular}

Note. ${ }^{*} p<.05,{ }^{* *} p<.01,{ }^{* * *} p<.001$. 
Our study examined the differential impact of digital skills (i.e., via mobile phones and computers) and access to open educational resources via both formal (computers at institutions such as Open University), and informal technologies (personal smartphones). Specifically, we assessed the differential effects of both types of communications on specific outcomes of functional literacy and perceived employability. Our findings revealed that access to OER resources via computers in the formal context of institutional learning had a significant influence on livelihood outcomes, i.e., perceived employability, when combined with employability awareness. However, this did not lead to actual improvements in learning- functional literacy. Instead, actual learning improvement as measured by functional literacy was influenced by personal attributes, such as mobile phone and computer skills.

These findings suggest that there are distinctions between institutionalized ICTs, such as computers available in classrooms for formal learning, versus organically diffused technologies such as mobile phones. We need to be nuanced in considering impact of OER for marginalized members of society who increasingly possess smartphones but can only experience computing in formal environments (Liebenberg, Chetty, \& Prinsloo, 2012). There are certain implications from these results. Past literatures that have largely discussed specific functional outcomes of technology in the context of ODL interventions have focused on the deployment of computers only (Jonassen, Davidson, Collins, Campbell, \& Haag, 1995; Olusola \& Alaba, 2011).

However, the importance of mobile phones in advancing migrant domestic workers' actual skills advances past research which has shown that mobile phones have been largely used by migrant workers for personal purposes (Chib et al., 2014; Thomas \& Lim, 2011). These personal uses seemed to have resulted in actual skills advancement, particularly in writing, reading, and counting, some of the most critical components embedded within the functional literacy concept. From a policy perspective, future guidelines in OER learning should go beyond computer-based learning in formal environments; mobile phone skills may provide benefits for migrant workers to support them in performing essential tasks in everyday living and eventually contribute to their pursuit of development.

It is interesting that access to OER resources did not significantly influence functional literacy. These findings appear to differ from those of Eady, Herrington, \& Jones (2010) and Silver-Pacuilla (2006), who found the effectiveness of institutionalized ICTs in improving literacy. The differences in findings may be due to the assumption in OER packages that users possess a minimum set of digital skills, thus putting the onus of intelligibility and productive usage on the users, which may vary considerably in low-income marginalized populations.

Access to OER via institutionalized use of computers was found to lead to migrant domestic workers' confidence level to secure employment in the future whereas doing so via informal ICTs, such as mobile phones, did not. This is a major finding that directed learning via instructors in formal classroom environments, coupled with OER curriculum design, is likely essential to be translated into livelihood outcomes. It may not be sufficient to hope that minimally educated, low-income populations can achieve livelihood outcomes by self-directed learning. If it were so, then the ubiquitous spread of mobile phones would solve the educational barriers in developing countries.

It is further interesting that functional literacy did not significantly influence perception of outcomes, yet employment awareness did. This implies that our migrant domestic workers participants believed that mere literacy would not be able to lead to better economic opportunities without self-motivation. A more nuanced analysis would integrate the constrained societal circumstances of these foreign domestic 
workers as an explanatory mechanism. With diminished labor mobility for blue-collar occupations, it is likely that the respondents valued the institutional credentials (e.g., diploma or certificate) obtained from the Open University over the personal achievement of functional literacy. We caution that structural factors of employment opportunities may have an important role to play in the perceived employability of marginalized sections of society, in addition to either their skillsets or agency.

Overall, our findings support the role of open educational resources in driving outcomes of perceived employability in the context of marginalized migrant females, earning meagre livelihoods as foreign domestic workers in the developed location of Singapore. However, we also note that these resources are not related to functional literacy, which is a function of users' own digital skills. The liberty for these migrant domestic workers to pursue higher education and non-discriminatory use of ICTs may contribute to a higher bargaining position for these women and to more equal opportunities between women and men in terms of skills advancement and employment opportunities. Benefits that they gain from education and ICTs are also hoped to have a far-reaching effect in that their perspective will further permeate in the way they choose to educate their children.

Conceptually, this study contributes to the body of knowledge in the area of open educational resources by broadening the assessment from ICTs at the institutional level to personal smartphones, and secondly emphasizing the impact of OER on specific livelihood outcomes. We provide new evidence of the differential effects of formal type of ICTs (i.e., computer) versus informal mobile phone usage in influencing functional literacy and perceived employability. Practically, higher education institution such as open universities may strengthen capacity of marginalized students in using, not only computers, but also mobile phones by organising programs that can support their skills advancement. Philosophically, we need to be aware of the structural disadvantages faced by marginalized communities in achieving employment objectives from institutional interventions.

Our study is limited by the cross-sectional nature, which did not allow the examination of ICTs usage on actual employment, or to claim causality. A longitudinal study where digital usages and skills are studied over a period of time would provide a more holistic assessment of causality. Another limitation pertains to the targeted sample of participants in the study which limits the replicability of the findings. The findings of this study do not represent migrant domestic workers in general because the OU students (i.e., participants in this study) were required to have a basic mastery of ICTs prior to enrolling, and we conducted this study in Singapore where ICT development and connectivity are high. We encourage future research investigating similar marginalized populations with varied digital skills in technologyrich contexts.

Understanding migrant domestic workers' ICTs skills in other environments warrants further investigation as the opportunities and barriers inter-context may be different. Future research might consider various factors from a structural perspective, combining two hitherto disparate concepts of technology-enabled learner support and the collaborative affordances of the technology (Thorpe, 2002) in situated contexts, incorporating structural issues of power imbalances and culture.

In conclusion, we note that "openness" is a conceptual construct that has significant potential for marginalized communities, such as female migrant domestic workers in our study. These range from benefits of perceived employability in institutionalized OER environments, and gains in functional literacy in self-directed digital learning from open access to communication technologies. However, open models are being applied, beyond distance learning (i.e., open-education), to other life domains such as 
access, data, development, governance, knowledge, publication, science, source, etc., as a means to improve the lives of millions of the downtrodden (Benkler, 2013). The field of ODL has the opportunity to form conceptual inter-disciplinary bridges by contributing to the discussion around what exactly is "open," be it the characteristics (Pomerantz \& Peek, 2016), practices (Lane, 2009), and/or processes (Smith \& Seward, 2017), particularly in evaluating the impact on the marginalized. We hope this article is a step in that direction. 


\section{References}

Ali, M., \& Samaka, M. (2013). Open education resources and mobile technology to narrow the learning divide. The International Review of Research in Open and Distributed Learning, 14(2), 14-27. http://dx.doi.org/10.19173/irrodl.v14i2.1530

Aricat, R. G., Karnowski, V., \& Chib, A. (2015). Mobile phone appropriation and migrant acculturation: a case study of an Indian community in Singapore. International Journal of Communication, 9, 22. Retrieved from http://ijoc.org/index.php/ijoc/article/view/3081

Atasoy, H. (2013). IT skills and employment opportunities of workers. NET Institute Working Paper No. 11-24. Retrieved from https://papers.ssrn.com/sol3/papers.cfm?abstract id=1958038

Atkinson, M. (2014). Reframing literacy in adult ESL programs: Making the case for the inclusion of identity. Literacy \& Numeracy Studies, 22(1), 3-20. doi:10.5130/lns.v22i1.4176

Barbeite, F. G., \& Weiss, E. M. (2004). Computer self-efficacy and anxiety scales for an Internet sample: testing measurement equivalence of existing measures and development of new scales. Computers in Human Behavior, 2o(1), 1-15. https://doi.org/10.1016/So747-5632(03)ooo49-9

Beckmann, E. A. (2010). Learners on the move: mobile modalities in development studies. Distance Education, 31(2), 159-173. http://doi.org/10.1080/01587919.2010.498081

Belt, V., \& Richardson, R. (2005). Social labour, employability and social exclusion: Pre- employment training for call centre work. Urban Studies, 42(2), 257-270. https://doi.org/10.1080/0042098042000316137

Benkler, Y. (2013). Foreword. In K. M. Reilly \& M. L. Smith (Eds.) Open development: Networked innovations in international development. MIT Press.

Bentley, C. M., \& Chib, A. (2016). The impact of open development initiatives in lower-and middle income countries: A review of the literature. The Electronic Journal of Information Systems in Developing Countries, 74(1), 1-20. Retrieved from http://cijournal.org/index.php/ciej/article/view/1423

Berntson, E., Sverke, M. \& Marklund. S. (2003). Predicting perceived employability: Human capital or labour market opportunities? Economic and Industrial Democracy, 27(2), 223-244. https://doi.org/10.1177/0143831X06063098

Brown, C., Murphy, T. J., \& Nanny, M. (2003). Turning techno-savvy into info-savvy: Authentically integrating information literacy into the college curriculum. The Journal of Academic Librarianship, 29(6), 386-398. https://doi.org/10.1016/j.jal.2003.08.005

Brown, P., Hesketh, A., \& Williams, S. (2003). Employability in a knowledge-driven economy. Journal of Education and Work, 16(2), 107-126. https://doi.org/10.1080/1363908032000070648

Carr-Hill, R. (2001). Wider benefits of learning: A review of the literature and models. London: 
Institute of Education.

Chib, A. \& Aricat, R. (2012). Seeking the non-developmental within the developmental: Mobile phones in the globalized migration context. In Emerging Economies, Emerging Technologies: Can Technology Make a Difference in Development? (pp. 153-167). New York: Routledge.

Chib, A., Wilkin, H. A., \& Mei Hua, S. (2013). International migrant workers' use of mobile phones to seek social support in Singapore. Information Technologies \& International Development, 9(4), pp-19. Retrieved from http://itidjournal.org/index.php/itid/article/view/1122

Chib, A., Malik, S., Aricat, R. G., \& Kadir, S. Z. (2014). Migrant mothering and mobile phones: Negotiations of transnational identity. Mobile Media \& Communication, 2(1), 73-93. doi:10.1177/2050157913506007

Cuban, S. (2014). Transnational families, ICTs and mobile learning. International Journal of Lifelong Education, 33(6), 737-754. doi:10.1080/02601370.2014.963182

de Hart, K. L., Chetty, Y. B., \& Archer, E. (2015). Uptake of OER by staff in distance education in South Africa. The International Review of Research in Open and Distributed Learning, 16(2). http://dx.doi.org/10.19173/irrodl.v16i2.2047

Diminescu, D. (2008). The connected migrant: an epistemological manifesto. Social Science Information 47(4), 565-579. https://doi.org/10.1177/0539018408096447

Eady, M., Herrington, A., \& Jones, C. (2010). Literacy practitioners' perspectives on adult learning needs and technology approaches in Indigenous communities. Australian Journal of Adult Learning, 5o(2), 260. Retrieved from https://search.proquest.com/docview/749780370?accountid=14548

Elias, N., \& Lemish, D. (2008). Media uses in immigrant families: Torn between "inward" and "outward" paths of integration. International Communication Gazette, 7o(1), 23-42. https://doi.org/10.1177/1748048507084576

Fugate, M., Kinicki, A. J., \& Ashforth, B. E. (2004). Employability: A psycho-social construct, its dimensions, and applications. Journal of Vocational behavior, 65(1), 14-38. https://doi.org/10.1016/j.jvb.2003.10.005

Garrido, M., Sullivan, J., \& Gordon, A. (2012). Understanding the links between ICT skills training and employability: An analytical framework. Information Technologies \& International Development, 8(2), 17-32. Retrieved from http://itidjournal.org/itid/article/view/895

Gerards, R., De Grip, A., \& Witlox, M. (2014). 'Employability-miles' and worker employability awareness. Applied Economics, 46(9), 952-965.

https://doi.org/10.1080/00036846.2013.864036

Haddon, L. (2000). Social exclusion and information and communication technologies lessons from studies of single parents and the young elderly. New Media \& Society, 2(4), 387-406. 
Harsasi, M. (2015). The use of open educational resources in online learning: A study of students' perception. Turkish Online Journal of Distance Education, 16(3), 74-87. Retrieved from https://eric.ed.gov/?id=EJ1092848

Hayes, E. R., \& Valentine, T. (1989). The functional literacy needs of low-literate adult basic education students. Adult Education Quarterly, 4O(1), 1-14. https://doi.org/10.1177/074171368904000101

Hillage, J., \& Pollard, E. (1998). Employability: developing a framework for policy analysis. London: DfEE.

Humanitarian Organization for Migration Economics. (2015). Home sweet home? Work, life and wellbeing of foreign domestic workers in Singapore (pp. 1-37). Singapore: Humanitarian Organization for Migration Economics. Retrieved from http://www.idwfed.org/en/resources/home-sweet-home-work-life-and-well-being-of-foreigndomestic-workers-in-singapore/@@display-file/attachment_1

Hsia, H., \& Smales, P. (2010, July 27-30). The power to organise and engage: The use of ICTs by women migrant domestic workers' organisations. CITIGEN Program Workshop. Bangalore, India. Retrieved from https://www.gender-iscitizenship.net/sites/default/files/citigen/uploads/DraftTT_cover.pdf

International Labour Organization. (2013). Domestic workers across the world: Global and regional statistics and the extent of legal protection. Retrieved from http://www.ilo.org/wcmsp5/groups/public/---dgreports/---dcomm/--publ/documents/publication/wcms_173363.pdf

International Labour Organization. (n.d.). Labour migration. Retrieved from http://www.ilo.org/global/topics/labour-migration/lang--en/index.htm

Jonassen, D., Davidson, M., Collins, M., Campbell, J., \& Haag, B. B. (1995). Constructivism and computer-mediated communication in distance education. American journal of distance education, 9(2), 7-26. https://doi.org/10.1080/08923649509526885

Kagitcibasi, C., Goksen, F., \& Gulgoz, S. (2005). Functional adult literacy and empowerment of women: Impact of a functional literacy program in Turkey. Journal of Adolescent \& Adult Literacy, 48(6), 472-489. https://doi.org/10.1598/JAAL.48.6.3

Keegan, D. (1996). Foundations of distance education. London: Routledge.

Kluzer, S., Ferrari, A., \& Centeno, C. (2009). ICT for learning the host country's language by adult migrants in the EU. Luxembourg: Office for Official Publications of the European Communities. Retrieved from https://delfiproject.files.wordpress.com/2011/04/jrc57387.pdf

Lane, A. (2009). The impact of openness on bridging educational digital divides. The International Review of Research in Open and Distributed Learning, 10(5). 


\section{http://dx.doi.org/10.19173/irrodl.v10i5.637}

Law, P. L., \& Peng, Y. (2006). The use of mobile phones among migrant workers in southern China. New Technologies in Global Societies (pp. 245-258). Singapore: World Scientific.

Levine, K. (1994). The social context of literacy. London: Routledge.

Liebenberg, H., Chetty, Y., \& Prinsloo, P. (2012). Student access to and skills in using technology in an open and distance learning context. The International Review of Research in Open and Distributed Learning, 13(4), 250-268. http://dx.doi.org/10.19173/irrodl.v13i4.1303

Lindsay, C. (2005). Employability, services for unemployed job seekers and the digital divide. Urban Studies, 42(2), 325-339. https://doi.org/10.1080/0042098042000316173

Madianou, M., \& Miller, D. (2011). Mobile phone parenting: Reconfiguring relationships between Filipina migrant mothers and their left-behind children. New Media \& Society, 13(3), 457-470. doi:10.1177/1461444810393903

Madigan, E. M., Goodfellow, M., \& Stone, J. A. (2007, March). Gender, perceptions, and reality: technological literacy among first-year students. In ACM SIGCSE Bulletin, 39(1), pp. 410-414). ACM.

McKenna, K. Y., \& Bargh, J. A. (2000). Plan 9 from cyberspace: The implications of the Internet for personality and social psychology. Personality and Social Psychology Review, 4(1), 57-75. https://doi.org/10.1207/S15327957PSPR0401 6

Ministry of Manpower. (2016). Foreign workforce numbers. Government of Singapore. Retrieved from http://www.mom.gov.sg/documents-and-publications/foreign- workforce-numbers

Mtebe, J. S., \& Raisamo, R. (2014). Investigating perceived barriers to the use of open educational resources in higher education in Tanzania. The International Review of Research in Open and Distributed Learning, 15(2). http://dx.doi.org/10.19173/irrodl.v15i2.1803

Nguyen, H., Chib, A., \& Mahalingam, R. (2017) Mobile phones and gender empowerment: Negotiating the essentialist-aspirational dialectic. Information Technologies \& International Development [Special Section], 13, 170-184. Retrieved from http://itidjournal.org/index.php/itid/article/view/1586/580

Olusola, A. J., \& Alaba, S. O. (2011). Globalization, information and communication technologies (ICTs) and open/distance learning in Nigeria: Trends, Issues and Solution. Turkish Online Journal of Distance Education, 12(3), 66-77. Retrieved from http://dergipark.ulakbim.gov.tr/tojde/article/view/5000102435

Orr, D., Rimini, M., \& Van Damme, D. (2015), Open Educational Resources: A Catalyst for Innovation, Educational Research and Innovation, OECD Publishing, Paris. http://dx.doi.org/10.1787/9789264247543-en

Park, Y. (2011). A pedagogical framework for mobile learning: Categorizing educational applications of mobile technologies into four types. The International Review of Research in Open and 
Distributed Learning, 12(2), 78-102. doi: http://dx.doi.org/10.19173/irrodl.v12i2.791

Perraton, H. (2012). Theory, evidence and practice in open and distance learning. Oldenburg: BISVerlag der Carl von Ossietzky Universität Oldenburg.

Pomerantz, J., \& Peek, R. (2016). Fifty shades of open. First Monday, 21(5), 80-85. https://doi.org/10.5210/fm.v21i5.6360

Qiu, J. L. (2009). Working-class network society: Communication technology and the information have-less in urban China. Cambridge, MA: MIT Press.

Reilly, K.M.A. \& Smith, M.L. (2013). The emergence of open development in a network society. In M. L. Smith \& K. M. A. Reilly (Eds.), Open development: Networked innovations in international development (pp. 15-50). Ottawa: The MIT Press.

Rothwell, A., \& Arnold, J. (2007). Self-perceived employability: development and validation of a scale. Personnel Review, 36(1), 23-41. https://doi.org/10.1108/00483480710716704

Saint, W. (2003). Tertiary distance education and technology in Sub-Saharan Africa. African Higher Education: An International Reference Handbook, 5(1), 93-111.

Selviandro, N., Suryani, M., \& Hasibuan, Z. A. (2014, February). Open learning optimization based on cloud technology: case study implementation in personalization E-learning. In Advanced Communication Technology (ICACT), 2014 16th International Conference on (pp. 541-546). IEEE.

Silver-Pacuilla, H. (2006). Access and benefits: Assistive technology in adult literacy. Journal of Adolescent \& Adult Literacy, 5o(2), 114-125. https://doi.org/10.1598/JAAL.50.2.4

Smith, J., McKnight, A., \& Naylor, R. (2000). Graduate employability: policy and performance in higher education in the UK. The Economic Journal, 11O(464), 382-411.

https://doi.org/10.1111/1468-0297.00546

Smith, M. L., \& Seward, R. (2017). Openness as social praxis. First Monday, 22(4). https://doi.org/10.5210/fm.v22i4.7073

Suhaida, M. A., Nurulhuda, M. S., \& Yap, S. F. (2013). Access to ICT as moderating factor to women's participation in the labor force: A conceptual framework. International Journal of Trade, Economics and Finance, 4(4), 197. doi: 10.7763/IJTEF.2013.V4.285

Thomas, M., \& Lim, S. S. (2011). On maids and mobile phones: ICT use by female migrant workers in Singapore and its policy implications. In J. E. Katz (Ed.), Mobile communication and social policy (pp. 175-190). Piscataway, NJ: Transaction.

Thompson, E. C. (2009). Mobile phones, communities and social networks among foreign workers in Singapore. Global Networks, 9(3), 359-380. https://doi.org/10.1111/j.14710374.2009.00258.x

Thorpe, M. (2002). Rethinking learner support: The challenge of collaborative online learning. Open 
Learning, 17(2), 105-119. https://doi.org/10.1080/02680510220146887a

Traxler, J. (2010). Distance education and mobile learning: Catching up, taking stock. Distance Education, 31(2), 129-138. http://doi.org/10.1080/01587919.2010.503362

UNESCO. (1978). Records of the general conference: Resolution, Vol. 1. UNESCO, Paris.

UNESCO. (2008). Education for all global monitoring report 2006. Retrieved from http://www.unesco.org/education/GMR2006/full/chapt1 eng.pdf

UNESCO. (2013). International migration report 2013. Retrieved from http://www.un.org/en/development/desa/population/publications/pdf/migration/migrationr eport2013/Full Document final.pdf

Wagner, E. (2005). Enabling mobile learning. Educause Review, 4O(3). Retrieved from https://www.learntechlib.org/p/99141/

Webb, S. (2006). Can ICT reduce social exclusion? The case of an adults' English language learning programme. British Educational Research Journal, 32(3), 481-507. https://doi.org/10.1080/0141192060063.5478

World Bank. (2013). ICTs are creating new jobs and making labor markets more innovative, inclusive, and global - World Bank study. Retrieved from http://www.worldbank.org

Young, S. S. C., \& Hung, H. C. (2014). Coping with the challenges of open online education in Chinese societies in the mobile era: NTHU OCW as a case study. The International Review of Research in Open and Distributed Learning, 15(3). http://dx.doi.org/10.19173/irrodl.v15i3.1742.

\section{Athabasca \\ University}

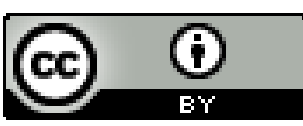

